\title{
The Philosophical Language of Death and Power
}

\author{
Jason L. Powell* \\ Department of Social and Political Science, University of Chester, CH1 4BJ, United Kingdom \\ *E-mail address: Jasonpwll3@gmail.com
}

\begin{abstract}
This article is concerned with understanding the relationship of philosophical languages of death with the social philosophy of Michel Foucault. Foucault's theoretical tools 'make sense' of languages of death in institutions such as care homes. While our responses to death and dying would seem to be very personal and therefore individually determined, they are, in fact, greatly influenced by the beliefs of individuals and "experts" who work in institutions providing care. Therefore, this article not only examines the limitations of bio-medicalized languages of death and dying, but importantly emphasises the importance of Foucault's conceptual tools to methodologically interrogate how death is managed in institutional care.
\end{abstract}

Keywords: Foucault; language; death; genealogy; power

\section{INTRODUCTION}

The language of 'death' has emerged as a significant issue and has now established itself as a core concern across humanistic and social sciences (Walter, 1999; Powell, 2012). Whilst the social study of death has played a key role in advancing a sociological understanding of its history and cultural construction (Walter, 1999, Hockey and James, 2001; Tulloch, 2006), there are contemporary social issues of death that can shed light on its social construction. Such a social constructionist approach comes from the philosophy of Michel Foucault. To expand, French Philosopher Foucault (1977) identifies three key processes in the objectification of individuals and how they were labelled in a particular culture. Hierarchical observation, the development of ever more sophisticated processes of surveillance (often discussed as 'panopticon' or the 'gaze') that are constantly but unobtrusively maintained, engulfing all in a web of watching (perpetual surveillance and round the clock care could be seen as one example). Normalizing judgements, the production of classification systems that enable the identification of 'norms' of social functioning that allow ongoing comparison of individuals enable small transgressions to become the focus of disciplinary attention and examination. An example would be what constitutes how 'death' is constructed is a normalizing process. If a 20 -year-old person were to die of an overdose - their death would be framed within a language of "tragedy" model and their life would need to be intensively investigated to see what had happened. If a 90 -year-old person were to die with a suspected overdose, their death would be framed within a language of "he was old anyway" (Powell, 2005). The power of language to classify people is the important point to note. Foucault (1977) links specific knowledges with particular practices in the exercise of power, while engaging experts [professionals] in a network of writing and documentary accumulation that 
identifies individuals as deserving or risky, noting individual features, specifying appropriate interventions and recording progress in relation to dying. Documentation fixes the objectification of individuals in writing, codifying, and calculating difference and drawing comparison and embedding this in language (for example, 'evidence-based practice') which, in turn, disciplines and regulates professional activity (Powell, 2005).

Since the construction of death mores has social implications, a major element of this article provides an investigation into the social construction of death grounded through a Foucauldian analysis. There has been a rapid acceleration in the social science literature that covers theoretical work under the aegis of "Foucauldian". Despite this, there has been a relative silence relating to using Foucault's rather unique methodological tools as applied to death studies (See Kastenbaum, 1997). It could have to do with the fact that Foucault's writings are complex and aphoristic to the extent that Foucault's approach was so "unmethodological" that his only apparently methodological work (The Archaeology of Knowledge, 1972) was really only a parody of devising a systematic methodology. So, why use Foucault to investigate social aspects of death? Foucault introduces the "history of the present" to provide a sensitizing context for understanding how the present is a product of the past. For example: what does the history of death look like? Historically, when did the encounter with the finality of death become more socially certain than a transition to immortality (when death was just a change in lifestyle)? How does the ethos of religion interpret what happens to a person when he or she dies?

A history of the present reveals the following: in all previous societies there were shared norms as to how to die and how to mourn. For example, the medieval ars moriendi applied to all, king and slave alike (Hawkins, 1990, p. 314); in seventeenth-century England, published deathbed accounts told Puritans the proper way to die; in the nineteenth century, magazines instructed the various social classes the appropriate length of mourning for particular categories of loss. What we find today is not a taboo, but a babel of voices proclaiming various good deaths (Kastenbaum, 1988; Hawkins, 1990, p. 314).

Death takes us, as individuals, to a place that exists at the brink of the crisis of modernity. We are not in control; we do not understand; our sense of self; our relations with others; even the way we experience time are challenged. Death imagery was pervasive in both fourteenth- and eighteenth-century Europe, probably because 'raw death' was a frequent intruder into everyday life (Aries, 1981, McManners, 1981). Both periods were also marked by preachings and writings that used the fear of death as an inducement to religious faith. Nevertheless, the nature of these two death-salient cultures also differed appreciably because the higher mortality rates and the associated fears were shaped respectively by late medieval and Enlightenment worldviews. For example, the people of both the fourteenth and eighteenth centuries would have been startled by 'painting the dead: portraiture and necrophilia in Victorian art and poetry (Christ, 1993). In turn, the Victorians would find much that is curious in our current death system - for example, medical technology, and controversy over the definition of death or deaths (Gervans, 1986; Seifert,1993). Bauman (1992, p, 18) argues that individuals attempt to belie the ultimate limitation of the body encountered in death by concentrating on its currently encountered specific limitations. In a culture of individualism that values a unique life uniquely lived, the good death is now the death that we can choose. For example, the good funeral ritual is the funeral that marks the passing of an individual. We have discarded the manuals of how to grieve and we now celebrate the 'difference' and 'diversity' of how funerals are conducted in relation to how one grieves through analysis of ritualism and social custom. This is very much related to how the past shapes the present. 
Moreover, it is through the process of "historical investigation" that social researchers can understand the present which takes aim at understanding Foucault's potential use of method to understand social formations relevant to social aspects of death. If 'historical inquiry' is to be used, researchers should "use it, to deform it, to make it groan and protest" (Foucault, 1980 , p. 54). Historical critique should be used to shatter 'taken-for-granted' assumptions surrounding death. The point of Foucault's $(1973 ; 1977)$ use of historical inquiry is to use 'history' as a way of diagnosing the present and current social arrangements. In order to understand the use of history in making sense of the present, we must introduce and analyze two concepts which are fundamental to languages of death namely: 'archaeology' and 'genealogy'.

\section{THE IMPORTANCE OF MICHEL FOUCAULT}

Michel Foucault's own approaches to the study of institutions were labelled in methodological terms as 'archaeological' and 'genealogical': the former involved isolating orders of language which laid down the conditions for articulating 'truths' (languages); the latter had more to do with non-discursive mechanisms of power which shaped the way individuals saw the world and acted within it (practices). For example, the various languages that make up a care assessment from social policy and consequent professional statements (articlework, assessing and monitoring) express the archaeological approach. However, another example focusing on genealogy reveals the architectural organisation of palliative care focuses on the spatial dimensions of such an institution, and the organization of such institutions are geared to care workers' surveillance and monitoring of patients' behavior (Powell and Biggs, 2000).

In general, Foucault uses these methodological "tools" to disrupt historical languages at the same time as giving languages and the non-discursive domains a power/knowledge reconfiguration. 'Languages' are sets of physical, behavioral and cognitive practices that generate knowledge of bodies, experience, phenomena and subjectivity. In The Birth of the Clinic Foucault's (1973) archaeology describes how physical examination practices in a medical clinic led to a way of using an 'inspecting gaze' that enabled physicians to develop an understanding of pathology and the body which in turn led to the development of medical power and scientific ideas pertaining to the body. Walter (2001) also adds 'death' to the consolidation of such 'expert' surveillance. The connection of 'power' is also important to note, as it exists in and through languages and relationships. Such languages gave the developing professional practices, such as the medical profession, disciplinary power over the dying body by rendering it an object to be understood through surveillance (Powell and Biggs, 2000; Powell, 2005). Similarly, Foucault's (1977) genealogical work, entitled Discipline and Punish analyzed the way in which the institutional prison system developed through 'panopticism'. The panopticon was a prison design by Bentham in which the spatial foundation of the prison had cells built around the periphery which surround a central tower. From all the cells, and subjects (prisoners) could be viewed. The very arrangement of the individualized cells ensures that those put under surveillance are hidden from each other; they can only watch themselves even when the tower is not watching them. As Foucault (1977, p. 200) points out 'the panoptic mechanism arranges spatial unities that make it possible to see constantly and to recognise immediately ... Visibility is a trap'. 
The next section looks to the relevance of archaeology and death in more depth.

\section{ARCHAEOLOGY AND DEATH}

In The Archaeology of Knowledge Foucault (1972) utilizes "archaeology" as the analysis of a statement as it occurs in the historical archive. He further points out that archaeology "describes languages as practices specified in the element of the archive" (1972, p. 131), The archive is "the general system of the formation and transformation of statements" (1972, p. 130). The use of an archaeological method explores the networks of what is said and what can be seen in a set of social arrangements: in the conduct of an archaeology there is a visibility in "opening up" statements. For example, Brooke-Ross (1986 cited in Langan and Lee, 1988) shows how palliative residential care as a form of visibility produces statements about the medical needs of people, while statements about death produce forms of visibility which reinforce the power of the institution (Allen et al, 1992). Such visibility and discursive configuration are emneshed with resource allocation too. Powell et al. (2005) claims the numbers of residential care places in the UK stood at 536,000 in the mid-1990s. They also claim that the financial cost of residential care stood at $£ 8$ billion per year - hence the consolidation of statements pertaining to aging reinforces the need for such institutions as residential care and the high revenue they generate. In this context, statements and visibilities mutually condition one another - they become interdependent upon each other. Furthermore, Biggs and Powell (2001) claim that, historically, social work as a visible social practice has produced negative statements about older age as synonymous with dominant bio-medical assumptions of 'decline', whilst managerialist statements about assessment reinforce the power of the professional and decrease the power and voice of the client (Biggs and Powell, 2000).

Archaeology can attempt to chart the relationship between statements and the visible; describe 'institutions' that acquire authority and provide limits within which discursive objects may exist. If we take these in turn we can illuminate its use to understanding death. Firstly, the attempt to understand the relation between statements and visibility focuses on those set of statements that make up institutions such as residential care: 'instructions' to care workers, statements about timetabling of activities for residents and the structure and space of the care institution itself (Powell and Biggs, 2000). Knowledge is composed of statements and visibility. In the example of residential care cited by Powell and Biggs (2000), we need to attend to both of what is said (particular bio-medical theories of caring) and what is visible (building, corridors and singular rooms). The crucial point is that a Foucauldian approach can draw our attention to the dynamic inter-relationship between statements and institutions, through the use of archaeology and genealogy. Secondly, the attempt to describe "institutions" which acquire authority and provide limits within which discursive objects may act, focuses again on the care institution which delimits the range of activities of discursive objects (Powell, 2001). 


\section{GENEALOGY AND DEATH}

Foucault acquired the concept of "genealogy" from the writings of Nietzsche. Genealogy maintains elements of archaeology including the analysis of statements in the archive (Foucault 1977 and 1982). With genealogy Foucault (1977) added a concern with the analysis of power/knowledge which manifests itself in the "history of the present". Foucault acquired the concept of "genealogy" from the writings of Nietzsche. Genealogy still maintains elements of archaeology including the analysis of statements in the "archive" (Foucault 1977, 1980 and 1982). With genealogy Foucault (1977) added a concern with the analysis of power/knowledge which manifests itself in the "history of the present". As Rose (1984) points out, genealogy concerns itself with disreputable origins and "unpalatable functions". This can, for example, be seen in relation to psycho-casework, care management and probation practice (Biggs and Powell 1999, 2001; May 1991; 1994). As Foucault found in his exploration of psychiatric power: 'Couldn't the interweaving effects of power and knowledge be grasped with greater certainty in the case of a science as 'dubious' as psychiatry?' (1980, 109)

Genealogy can be distinguished from archaeology in it approach to discourse. Whereas archaeology provides a snapshot, a 'slice' through the discursive nexus, genealogy focuses on the processual aspects of the web of discourse - its ongoing character (Foucault, 1980). Foucault did attempt to make the difference between them explicit: 'If we were to characterise it in two terms, then 'archaeology' would be the appropriate methodology of this analysis of local discursiveness, and 'genealogy' would be the tactics whereby, on the basis of the descriptions of these local discursivities, the subjected knowledge's which were thus released would be brought into play' (Foucault 1980, 85).

Foucault is claiming that archaeology is a systematic method of investigating official statements such as dispostifs (McNay, 1994). Genealogy is a way of putting archaeology to practical effect, a way of linking it to cultural concerns: 'A genealogy of values, morality, asceticism, and knowledge will never confuse itself with a question for their 'origins', will never neglect as inaccessible the vicissitudes of history. On the contrary, it will cultivate the details and accidents that accompany every beginning; it will be scrupulously attentive to their petty malice; it will await their emergence, once unmasked, as the face of the other. Wherever it is made to go, it will not be reticent - in 'excavating the depths', in allowing time for these elements to escape from a labyrinth where not truth had ever detained them. The genealogist needs history to dispel the chimeras of the origin, somewhat in the manner of the pious philosopher who needs a doctor to exorcise the shadow of his soul. Foucault's use of genealogy cannot be divorced from an understanding of power, nor can the constitution of the subject. With this in mind our approach will be to consider his analytical ingenuity via an examination of different modes through which 'subjectivity' is constituted. Foucault (1977) grounded this as a pivotal mode of analysis that has been deployed in reflections on his own life. Subjectivity appears as both an experiential and discursive strategy that 'goes beyond theory' and provides us with a way to problematise the explanatory value and relevance of his analyses.

As Foucault (1982) points out, genealogy concerns itself with disreputable origins and "unpalatable functions". For example, Biggs and Powell's $(2000,2001)$ genealogy of psychocasework and care management points to the origins and functions of gerontological social work as a scientific and managerialist profession are far from the levels of benevolence that official histories of professional practice with older people would have us believe. As Foucault (1982, p. 109) found in his subjective exploration of power: 'Couldn't the 
interweaving effects of power and knowledge be grasped with greater certainty in the case of a science as 'dubious' as medicalization?'.

This section discusses the institutional medicalization of terminally ill people and the institutions that care for dying people. The loss of living identity can occur long before medical death, and 'social death' can be said to occur: when the body comes to occupy certain spaces defined by the its disconnection from a wider social network. They are, as Hockey (1990) explains, dying spaces. We look at a range of institutions, such as hospice, nursing and residential homes and raise critical questions as to how certain people are not so much cared for, but - as Clough (1995) points out - are medicalized and abused to death. We will examine the medicalization of death and disease perception and the medicalization of the struggle against death, as well as the possibilities of a de-medicalization of these phenomena. Our engagement with death us increasingly mediated by a series of institutional and professional practices (Giddens, 1991). Their intervention has produced transformations in social norms and behavioral habits that relate to death. We should question to what degree, as individuals, we are shaped by the medical ideology in which we were brought up and socialized; and the strength of medical values. We should also question how well founded is western culture's overwhelming scientific belief in the progress and superiority of modern medicine and the creation of institutions to manage dying and death. The medical establishment has produced an ageing population requiring ever greater services, with over 500,000 older people who are residential/nursing home residents in the United Kingdom. Old age has increasingly become equated with the dying process. To exemplify this, Clough (1988) completed a study of elder abuse at an institutional 'residential care' home in England. Many staff had neglected older residents, including neglecting to bathe residents; punishing those residents leaving hot water running in bathrooms; opening windows for air; and staff removed blankets from residents leading to pneumonia and subsequently many deaths. Hence, the power/knowledge twist of professional 'caregivers' was detrimental to older people's "quality of life" in residential care. Such care action was a powerful and repressive mechanism of disciplination used to indent and strip the identities of patients.

In a similar context, Goffman (1968) wrote about how spatial arrangements of 'total institutions' (prisons) operate to provide care and rehabilitation at an official level and capacity, underneath the surface, however, such institutions curtail the rights of its prisoners:

Many total institutions, most of the time, seem to function merely as storage dumps for inmates ... but they usually present themselves to the public as rational organizations designed consciously, through and through, as effective machines for producing a few officially avowed and officially approved ends. (Goffman, 1968, p. 73)

Furthermore, as Powell and Biggs (2000) point out, a genealogical argument as relates professional power involves: '... uncloaking these power relations [and] is characterised, by Foucault, to set out to examine the "political regime of the production of truth" (Davidson, 1986, p. 224).

The effects of the relationship between 'power' and 'knowledge' would include the tendency for professional power to be reinforced by the sort of questions professionals ask and the data they collate on individuals and populations (Nettleton, 1995; Powell, 2001). By the same effect, various social policy positions point professionals to seek out certain forms of knowledge which tend to reinforce the position of that policy and its associated languages in relation to the object form of study (Biggs and Powell, 2001). As part of this process, certain 
powerful voices increase their legitimacy, whilst other voices become silenced and delegitimized (Biggs and Powell, 2001).

Coupled with this, there are a number of wider research studies which give rich insights into the power of institutions that give out the discursive "death penalty". The "death penalty" impinges on the social construction of death. We can see the relationship between the State's use of the death penalty as a mode of punishment for offenders. There are a varieties of 'death penalties' utilized in Western countries - for example, in the United States and in the developing world. We can look at the history of the present of the use of 'beheading', 'stoning to death', 'lethal injection', ' the gas chamber' and 'the electric chair', 'hanging', 'the firing squad' or that death should not be replaced by living death. Foucault (1977) argues that, to offer as an alternative to capital punishment the mandatory use of lifelong imprisonment without the possibility of parole would be, to offer one human rights abuse in return for another. From 1977 to 2002, the number of prisoners put to death in the United States totalled 820 (Welch, 2005). Hence, there are moral and ethical dimensions to whether the death penalty should be seen in utilitarian terms, or whether the death of a single innocent person is sufficient to dissuade the State from the use of this ultimate punishment. Hence, a variety of care and criminal justice/state institutions play an enormous power role in shaping death practices.

From this, there are two aspects of Foucault's concepts relevant to an analysis of institutional power and death: firstly, there is the assessment of changing ways of constructing knowledge and professional practices (Biggs and Powell, 2000); secondly, there is the identification of the objects/subjects that are problematized through shifting languages that embody changing professional knowledge bases and practice (Powell, 2001).

What is clear is that genealogy establishes itself as different from archaeology in its approach to language. Where archaeology provides gerontology with a snapshot, a slice through the discursive nexus, genealogy focuses on the processual aspects of the web of language - its ongoing character (Foucault 1982). Foucault (1982) did attempt to make the difference between both methodological concepts explicit:

If we were to characterise it in two terms, then 'archaeology' would be the appropriate methodology of this analysis of local discursiveness, and 'genealogy' would be the tactics whereby, on the basis of the descriptions of these local discursivities, the subjected knowledges which were thus released would be brought into play. (Foucault, 1982, p. 85)

Foucault talks about how power plays a role in reinforcing knowledge of experts and institutions. For example, we can see how the death of particular groups in War between States and "terrorist" organisations is a relation of power/knowledge fighting for legitimacy of action in order to illuminate that their cause is the only cause; the legacy of 9/11 as well as the implications of the 'War on Terror'. What constitutes legitimate and illegitimate versions of death as understood through comparing war and terrorism? Only by examining the underlying causes and effects of terrorism, including political and ideological crime, ranging from mass destruction to assassination. If we look at specific wars and the implications this has on populations: from Hitler's regime and the death of six million Jewish people; War in Cambodia in the 1990s that led to three million deaths; the War in the former Republic of Yugoslavia led to two million deaths; and the War in Iraq that has led to 100,000 deaths. Similarly, certain terrorist organizations, such as Al Qaeda, have caused many civilian deaths, ranging from the 9/11 atrocities through the killing of people in Iraq to the Irish Republican 
Army's (IRA) historical campaign of political violence in the context of bombings in England and to the Hezzbolah in the Middle East.

Hence, across history, we can see the extent to which 'war' and 'terrorism' are two sides of the same coin: terrorism both internal and trans-national has unprecedented potential for undermining both human societies and individual lives. Therefore:

Foucault identified languages as historically variable ways of specifying knowledge and truth. They function as sets of rules, and the exercise of these rules and languages in programmes which specify what is or is not the case - what constitutes 'terrorism', for example. Those who are labelled 'terrorist' are in the grip of power. (Biggs and Powell, 2001, p. 97).

The important issues that Foucault raises via a questioning of the centrality of the subject are associated to 'truthful' formulations of the task or the problem that certain domains of experience and activity pose for individuals themselves involve the social construction of power. The boundaries of self-experience change with every acquisition, on the part of individuals, of a possibility, or a right, or an obligation, to state a certain 'truth' about themselves. For example, bio-technology in popular culture can tell a 'truth' of selling a dream of unspoken desire of 'not growing old' to people. However, it is the self-experience of subjects that can refute, deny and accept the 'truth' claims of bio-technology. In the case of lifestyles in popular culture, the active adoption of particular consumer practices, such as uses of bio-technology contributes to a narrative that is compensatory in its construction of self (Biggs and Powell, 2001). Thus, the recourse to the notion of technologies of self is capable of accommodating the complexity of the 'subject'.

Although Foucault maintained the distinction between the technologies of power/domination and the technologies of self, these should not be regarded as acting in opposition to or in isolation to one another. Indeed, Foucault frequently spoke of the importance of considering the contingency of both in their interaction and interdependence, by identifying specific examples. The point where the technologies of domination of individuals over one another have recourse to processes by which the individual acts upon himself and, conversely, the points where the technologies of the self are integrated into structures of coercion.

\section{CONCLUSION}

This article has set out an initial assessment and contextualization of Foucault's methodological contribution to understanding death and its relations to institutions of power. What makes Foucault's overall theoretical work inspiring, is how he animates and locates problems of knowledge as 'pieces' of the larger contest between modernity and its subjects. By downplaying the individual subject, Foucault shows how 'bodies' and 'populations' are sites were 'human beings are made subjects' by 'power/knowledge' practices. Archaeology and genealogy are highly relevant to the analysis of surveillance and the social construction of individuals as objects/subjects of knowledge: archaeology has been useful to assess historical narratives which bring light to discursive formations that have produced fields of knowledge pertaining to professional power and the shaping of social phenomena for objects of study; genealogy is the attempt to uncover the historical relationship between truth, knowledge and power. As I hinted at earlier through the analysis of the work of Nettleton (1992), 
power/knowledge is produced through 'struggles' and 'negotiations' both between and within institutions. Indeed, using such distinctive methodologies of archaeology and genealogy reveals relations of power and power relationships between professionals, institutions and subjects of study, while demonstrating the relevance to uncovering languages of death relating to the construction of knowledge about the nature of individuality and the control of such knowledge bases. While our responses to death and dying would seem to be very personal and therefore individually determined, they are, in fact, greatly influenced by the beliefs of society which seep into the fabric of institutional power.

\section{Author's biography}

Hon Professor Jason L. Powell BA (Hons), MA, Ph.D, FRSA is University Lecturer, Honorary Professor and Adjunct Professor. He is formerly Professor of Social Gerontology and Associate Dean of Faculty of Health and Life Sciences at University of Coventry. He holds an Honorary Fellowship at University of Liverpool; Honorary Professor at Australia-Asia Research and Education Foundation at Tasmania University; Visiting Research Fellow at Oxford; and recently invited as Visiting Scholar at Harvard University. He has been Visiting Professor in Canada, US, Australia, Africa and Jordan. He was nominated and elected to Fellowship of the British Royal Society of Arts (FRSA) in recognition of his research. He has strong interests in social theory, ageing, power and identity. He is author of Social Theory and Ageing (2006) which was part of Charles Lemerts distinguished New Social Formations book series, Rowman and Littlefield: New York.

\section{References}

[1] Aries, P (1981) The hour of death. New York Alfred A Knopf.

[2] Armstrong, D (1983) Political Anatomy of the Body: Medical Knowledge in Britain in the Twentieth Century, Cambridge, Cambridge University Press.

[3] Bauman, Z (1992) 'Survival as a Social Construct', Theory, Culture and Society, 99: 136.

[4] Christ, C (1993) Painting the Dead: Portraiture and Necrophilia in Victorian art and poetry in S. W. Goodwin and E. Bronfen (eds) Death and Representation (pp. 131-151) Baltimore: John Hopkins University Press.

[5] Crossley, N. (2001) The Social Body: Habit, Identity and Desire, London, Sage.

[6] Biggs, S and Powell, J (2000) 'Surveillance and Elder Abuse: The Rationalities and Technologies of Community Care' in Journal of Contemporary Health, 4, 1, 43-49.

[7] Biggs, S and Powell, J (2001) 'A Foucauldian Analysis of Old Age and the Power of Social Welfare', Journal of Aging \& Social Policy, 12, 2, 93-112.

[8] Bloor, M and McIntosh, J (1990) 'Surveillance and concealment', in Cunningham Burley, S and McKegany, N (Eds.) Readings in Medical Sociology, London: Routledge

[9] Brooke-Ross, R (1986) quoted in Langan, M and Lee, P (Eds.) (1988) Radical Social Work Today, London: Unwin Hyman.

[10]Clough, R (1988) Practice, Politics and Power in Social Service Departments, Aldershot: Gower 
[11]Hadley, R and Clough, R (1996) Care in Chaos, London: Cassel

[12]Davidson, A. (1986). 'Archaeology, Genealogy, Ethics' in Hoy, D (Ed.). Foucault: a critical reader. Oxford: Basil Blackwell.

[13]Foucault, M (1965) Madness and Civilization, London: Tavistock.

[14]Foucault, M (1973) The Birth of the Clinic, London: Routledge.

[15]Foucault, M (1977) Discipline and Punish, London: Penguin.

[16]Foucault, M (1978) The History of Sexuality, Vol.1, London: Penguin.

[17]Foucault, M (1982) 'The subject of Power' in Dreyfus, H and Rabinow, P (Eds.) Michel Foucault: beyond structuralism and hermeneutics, Brighton: Harvester.

[18] Goffman, E (1968) Total Institutions

[19] Gervins, K.G (1986) Redefining Death. New York Haven: Yale University Press.

[20] Giddens, A (1991) Modernity and Self-Identity, Cambridge: Polity.

[21] Hawkins, A.H (1990) Constructing Death: three pathographies about dying, Omega 22,4: 301-17.

[22] Howarth, G. Death and Dying : A Sociological Introduction, Cambridge, Policy Press.

[23] Kastenbaum, R (2005) Death, Society and Human Experience ( $9^{\text {th }}$ Edition) Boston: Allyn and Beacon.

[24] Kastenbaum, R (1988) Safe Death in the Postmodern World, in A. Gilmore and S. Gilmore (eds) A Safer Death, London, Plenum.

[25]Luckmann, T (1967) The Invisible Religion: The Problem of Religion in Modern Society: New York: Macmillan.

[26] McManners, J (1981) Death and the Enlightenment, Oxford, New York, Oxford University Press.

[27] Mellor, P. A. and Shilling C (1993), Modernity, Self-Identity and the Sequestration of death, Sociology . Vol 27.

[28] Morgan, D. H. J and Scott, S (1993) Bodies in a social landscape, in D.H.J Morgan and S. Scott (eds), Body Matters : Essays on the sociology of the body, London: The Falmer Press.

[29] Powell, J. L and Biggs, S (2000) 'Managing Old Age: The Disciplinary Web of Power, Surveillance and Normalization', Journal of Aging \& Identity, 5 (1), 3-13

[30] Powell, J. L (2001) 'Theorizing Gerontology: The Case of Old Age, Professional Power and Social Policy in the United Kingdom', Journal of Aging \& Identity, 6, 3, 117-135

[31]Powell, J.L (2005) Social Theory and Aging, Rowman and Littlefield: Lanham

[32]Powell, J.L. (2012). Foucault. Nova Science: New York.

[33] Seifert, J (1993) Is 'brain dead' actually death? The monist in the International Journal of General Philosophical inquiry, 76, 175-202.

[34] Shildrick, M (2002) Embodying the Monster: Encounters with the Vulnerable Self, London, Sage. 
[35] Shilling, C (1993), The body and social theory London Sage.

[36] Turner, B. S (1991) Religion and Social Theory, London: Sage.

[37] Walter T (1993) Death in a New Age, Religion 23, 2:127-145 .

[38] Walter, T (1999) On Bereavement, OUP

[39] Welch, M (2005) Ironies of Imprisonment, London: Sage

( Received 12 February 2015; accepted 19 February 2015 ) 